\title{
Early PCR-based detection of Fusarium culmorum, $F$. graminearum, $F$. sporotrichioides and $F$. poae on stem bases of winter wheat throughout Poland
}

\author{
A. Kuzdraliński • H. Szczerba • K. Tofil • A. Filipiak • \\ E. Garbarczyk • P. Dziadko • M. Muszyńska • \\ E. Solarska
}

Accepted: 10 July 2014 / Published online: 16 August 2014

(C) The Author(s) 2014. This article is published with open access at Springerlink.com

\begin{abstract}
Foot rot and crown rot are fungal diseases of wheat caused by a complex of Fusarium species. They have a huge economic impact mainly due to yield reduction. A survey was conducted to identify four Fusarium species, occurring on wheat stem bases, using speciesspecific PCR assays in samples collected during spring of 2012. The dominant species was $F$. graminearum, which was identified in above $64 \%$ of samples. F. culmorum was detected in $15.71 \%, F$. poae in $15.71 \%$ and F. sporotrichioides in $5.71 \%$ wheat fields. Most of the wheat fields in the eastern Poland were infected with at least one or two of Fusarium species, while in central Poland no Fusarium species were identified in most of the fields. The presence of $F$. graminearum tends to favor the presence of $F$. culmorum and this effect was visible also for $F$. poae and $F$. sporotrichioides. The frequency of F. graminearum and F. culmorum detections were highest where wheat crops were preceded by maize and in the samples from late sown fields. The opposite observation was made for $F$. poae and $F$. sporotrichioides, where the number of detections of these species was higher in samples from early sown fields. The number of detected Fusarium species was significantly lower in samples collected from fields protected with autumn herbicide in comparison to unprotected fields. The rate of autumn $\mathrm{N}$
\end{abstract}

\footnotetext{
A. Kuzdraliński $(\bowtie) \cdot H$. Szczerba $\cdot K$. Tofil $\cdot$ A. Filipiak E. Garbarczyk · P. Dziadko • M. Muszyńska • E. Solarska Department of Biotechnology, Human Nutrition and Science of Food Commodities, University of Life Sciences in Lublin, ul. Skromna 8, 20-704 Lublin, Poland e-mail: adamkuzdralinski@gmail.com
}

fertilization did not affect the number of Fusarium detections.

Keywords Fusarium $\cdot$ Winter wheat $\cdot$ Species-specific PCR - Stem base

\section{Introduction}

The genus Fusarium contains many plantpathogenic fungi, which are responsible for three main diseases of cereals: Fusarium head blight (FHB), foot rot (FR) and crown rot (CR). FHB is the best known Fusarium disease mainly due to the deterioration of grain quality through the production of mycotoxins (Parry et al. 1995; Champei et al. 2004; Gargouri et al. 2011). FR and CR are also a major problem in the production of wheat, causing significant yield losses each year (Smiley and Patterson 1996). CR can cause up to $89 \%$ loss of wheat yield (Klein et al. 1991).

F. graminearum, F. pseudograminearum and F. culmorum have been identified as the predominant species associated with these diseases. Less frequently isolated species are F. poae, F. sporotrichioides, $F$. acuminatum, F. avenaceum, F. crookwellense, $F$. oxysporum and F. equiseti (Braithwaite et al. 1998; Bottalico and Perrone 2002; Monds et al. 2005). The relationship between FR, CR and FHB caused by the same fungi from the genus Fusarium is generally unclear (Parry et al. 1995). Fusarium spp. causing FR and CR survive in dead plant material or in the soil. Necrosis 
Table 1 Samples collected from winter wheat fields in the spring of 2012 along with their geographic origin, forecrop, date of sowing and nitrogen level fertilization

\begin{tabular}{|c|c|c|c|c|}
\hline Sample & Geographic region & Forecrop & Date of sowing & $\begin{array}{l}\mathrm{N} \text { fertilization } \\
{[\mathrm{kg} / \mathrm{ha}]}\end{array}$ \\
\hline 1 & central Poland & winter rape & mid-September & 5 \\
\hline 2 & central Poland & winter rape & mid-September & 0 \\
\hline 3 & central Poland & winter rape & mid-September & 50 \\
\hline 4 & eastern Poland & maize & early October & 22,2 \\
\hline 5 & eastern Poland & winter wheat & early September & 58 \\
\hline 6 & north-westernPoland & winter rape & early October & 0 \\
\hline 7 & north-westernPoland & winter rape & late September & 16 \\
\hline 8 & north-westernPoland & winter rape & mid-September & 40 \\
\hline 9 & north-westernPoland & maize & early October & 0 \\
\hline 10 & north-westernPoland & winter wheat & mid-September & 55 \\
\hline 11 & eastern Poland & winter wheat & mid-September & 52 \\
\hline 12 & eastern Poland & winter wheat & early September & 8 \\
\hline 13 & north-westernPoland & winter rape & mid-September & 40 \\
\hline 14 & north-westernPoland & maize & late September & 0 \\
\hline 15 & north-westernPoland & winter barley & mid-September & 0 \\
\hline 16 & eastern Poland & white beet & early October & 30 \\
\hline 17 & north-westernPoland & winter rape & late September & 0 \\
\hline 18 & central Poland & winter wheat & mid-September & 30 \\
\hline 19 & north-westernPoland & winter wheat & late September & 0 \\
\hline 20 & north-westernPoland & winter rye & early October & 0 \\
\hline 21 & north-westernPoland & winter barley & late September & 0 \\
\hline 22 & central Poland & winter rape & late September & 0 \\
\hline 23 & south-western Poland & maize & mid-October & 0 \\
\hline 24 & south-western Poland & winter rape & late September & 0 \\
\hline 25 & south-western Poland & winter rape & mid-September & 12 \\
\hline 26 & south-western Poland & maize & early October & 0 \\
\hline 27 & south-western Poland & winter rape & late September & 28 \\
\hline 28 & south-western Poland & maize & early October & 0 \\
\hline 29 & south-western Poland & maize & mid-October & 0 \\
\hline 30 & south-western Poland & maize & mid-October & 10 \\
\hline 31 & south-western Poland & maize & mid-October & 34 \\
\hline 32 & eastern Poland & winter rape & mid-September & 110 \\
\hline 33 & south-western Poland & winter rape & mid-September & 0 \\
\hline 34 & south-western Poland & winter wheat & mid-October & 0 \\
\hline 35 & south-western Poland & maize & early October & 0 \\
\hline 36 & south-western Poland & winter rape & late September & 18 \\
\hline 37 & north-westernPoland & lupine & late September & 0 \\
\hline 38 & central Poland & nd & nd & nd \\
\hline 39 & north-westernPoland & winter wheat & mid-September & 0 \\
\hline 40 & central Poland & winter wheat & mid-September & 0 \\
\hline 41 & central Poland & winter wheat & nd & 18 \\
\hline 42 & south-western Poland & maize & late October & 0 \\
\hline 43 & south-western Poland & winter wheat & mid-October & 0 \\
\hline
\end{tabular}


Table 1 (continued)

\begin{tabular}{|c|c|c|c|c|}
\hline Sample & Geographic region & Forecrop & Date of sowing & $\begin{array}{l}\mathrm{N} \text { fertilization } \\
{[\mathrm{kg} / \mathrm{ha}]}\end{array}$ \\
\hline 44 & north-westernPoland & spring wheat & late September & nd \\
\hline 45 & north-westernPoland & winter rape & late September & 0 \\
\hline 46 & north-westernPoland & white beet & mid-September & 0 \\
\hline 47 & eastern Poland & winter rape & late September & 20 \\
\hline 48 & central Poland & winter rape & mid-September & 20 \\
\hline 49 & south-western Poland & maize & late September & 10 \\
\hline 50 & north-westernPoland & white beet & early September & 15 \\
\hline 51 & south-western Poland & triticale & nd & nd \\
\hline 52 & north-westernPoland & winter rape & nd & nd \\
\hline 53 & eastern Poland & winter rape & mid-September & 20 \\
\hline 54 & eastern Poland & winter wheat & mid-September & 20 \\
\hline 55 & central Poland & winter wheat & early October & 250 \\
\hline 56 & south-western Poland & winter rape & late September & 0 \\
\hline 57 & south-western Poland & winter rape & nd & nd \\
\hline 58 & south-western Poland & white beet & nd & nd \\
\hline 59 & south-western Poland & winter rape & late September & 0 \\
\hline 60 & north-westernPoland & winter wheat & early September & 30 \\
\hline 61 & north-westernPoland & winter wheat & mid-September & 30 \\
\hline 62 & eastern Poland & nd & nd & nd \\
\hline 63 & eastern Poland & winter rape & late September & 60 \\
\hline 64 & central Poland & winter wheat & mid-September & 0 \\
\hline 65 & eastern Poland & winter wheat & mid-September & 35 \\
\hline 66 & central Poland & maize & late October & 15 \\
\hline 67 & eastern Poland & winter wheat & mid-September & 18 \\
\hline 68 & eastern Poland & spring wheat & mid-September & 18 \\
\hline 69 & central Poland & white beet & early November & 0 \\
\hline 70 & south-western Poland & winter rape & late September & 0 \\
\hline
\end{tabular}

$n d$ no data available

of the crown and stem base of wheat are the main symptoms of FR and CR. In some cases, severe disease occurrence contributes to premature death of the whole plants. Residual stubble has been identified as the source of primary infection but still little is known about the basis of the infection process (Burgess et al. 2001). Many authors highlight the fact that host residues for Fusarium spp. inoculum depends on cultivation method, cropping sequence and herbicide usage (Wiese 1987; Cromey et al. 2006). The few studies conducted in Poland have reported that the presence of Fusarium spp. on stem bases of winter wheat depends mainly on the weather and to a lesser extent on the crop rotation and weed infestation (Jaczewska-Kalicka 2001; Korbas 2004; Narkiewicz-Jodko et al. 2005).

Identification of fungi of the genus Fusarium, based on the morphology of mycelium and macroconidia, is a reliable method but it requires time and necessary skills. The polymerase chain reaction (PCR) technique is one of the most frequently used molecular tools for rapid and sensitive identification of Fusarium species (Niessen et al. 2004; Mulé et al. 2005; Demeke et al. 2005; Jurado et al. 2005, 2006).

In this study, we report the incidence of four important Fusarium species on stem bases of winter wheat in Poland. The selected species of $F$. graminearum, $F$ 


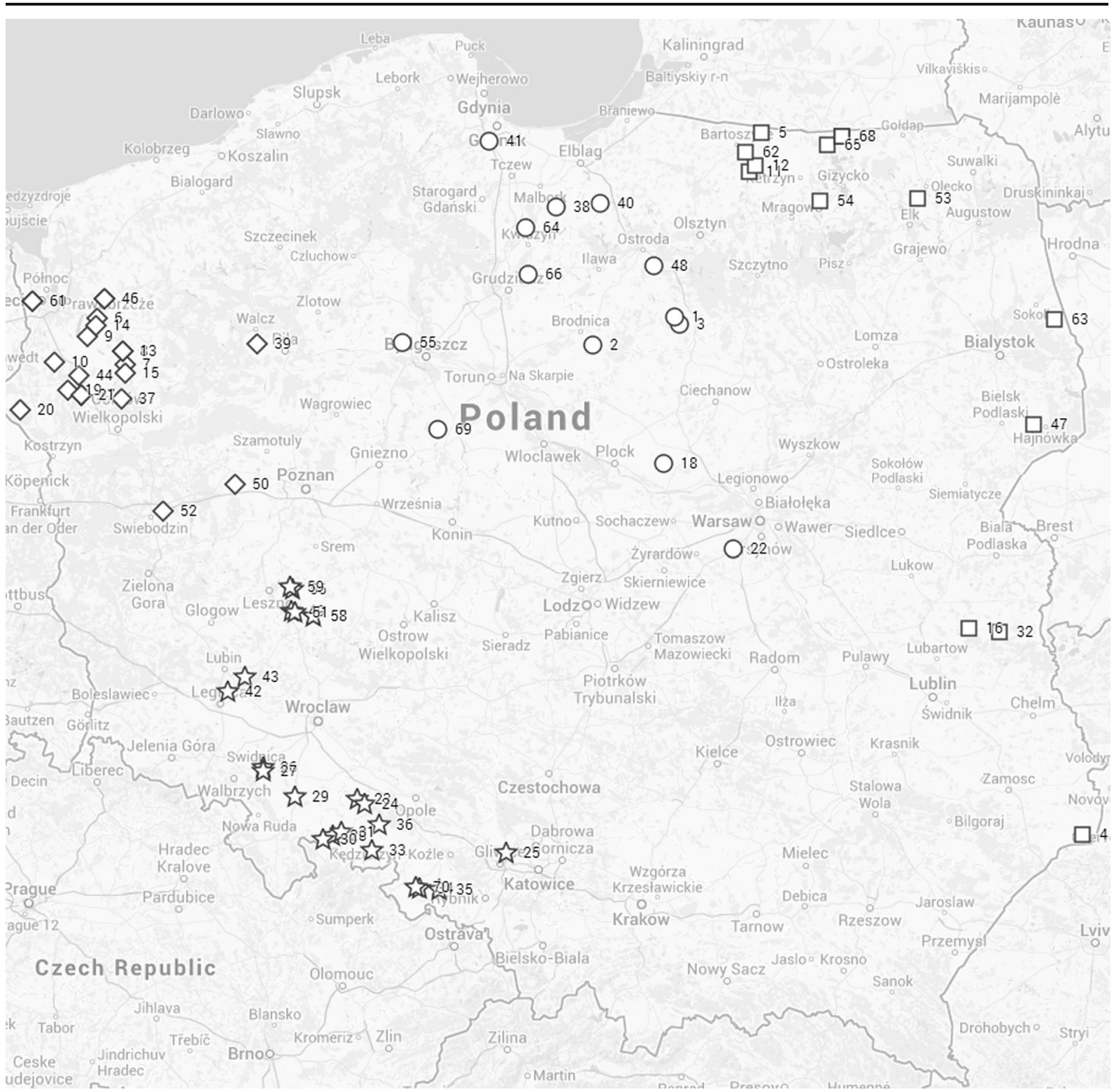

Fig. 1 Map of Poland (Google Maps Engine Lite, Liebert 2013) showing the location of sites of collection of winter wheat plants. Samples were divided into four groups with respect to geographic and climatic regions and marked with different icons: square eastern Poland, circle - central Poland, star - south-western Poland and diamond - north-western Poland .culmorum, F. poae and F. sporotrichioides are the prevalent causal agents of Fusarium diseases of roots and stem bases of wheat in Poland (Baturo 2006; Łukanowski 2009; Mielniczuk et al. 2012). We have determined their relationships with the following important factors: geographic region, previous crop, herbicide application, date of sowing and rate of autumn nitrogen fertilization. Lastly, we evaluate the interactions between Fusarium species tested in this work.

\section{Materials and methods}

Sample collection

Samples of winter wheat plants were collected in the spring of 2012 from 70 fields located in Poland during the tillering and just before the stem elongation stage of the crop growth (Table 1, Fig. 1). The number of plants collected varied slightly at each site, ranging from 10 to 
Table 2 Species-specific primers used to identify Fusarium species

\begin{tabular}{lllll}
\hline Target species & Primer name & Sequence 5'-3' & Amplicon size (bp) & Reference \\
\hline F. graminearum & Fg16NF & ACAGATGACAAGATTCAGGCACA & 280 & Nicholson et al. 1998 \\
& Fg16NR & TTCTTTGACATCTGTTCAACCCA & & Nicholson et al. 1998 \\
F. culmorum & Fc01F & ATGGTGAACTCGTCGTGGC & 570 & Parry and Nicholson 1996 \\
& Fc01R & CCCTTCTTACGCCAATCTCG & & Kulik et al. 2004 \\
F. poae & Fp82F & CAAGCAAACAGGCTCTTCACC & 220 & \\
& Fp82R & TGTTCCACCTCAGTGACAGGTT & & \\
& FspITS2K & CTTGGTGTTGGGATCTGTGTGCAA & 288 & \\
& P28SL & ACAAATTACAACTCGGGCCCGAGA & & \\
\hline
\end{tabular}

20 plants, depending on the size of the field. Growers were provided with a questionnaire to supply information on previous crop, sowing date, autumn herbicide and fertilizer applications. Each sample was transported to the laboratory where it was stored at $-20^{\circ} \mathrm{C}$.

\section{DNA extraction}

The leaf sheaths of each plant were removed and stems were washed carefully with tap water to remove adhering soil. Single stem sections between the crown roots and the first node $(0.5-1 \mathrm{~cm}$ in length) were removed from each stem and used for DNA isolation. DNA was extracted from 15- to 25-mg subsamples of wheat stem bases that were transferred to $2 \mathrm{ml}$ Eppendorf tube and pestled with liquid nitrogen to a fine powder. DNA from stem bases was obtained using Plant and Fungi Kit (EURx, Poland) according to the manufacturer's instruction. DNA purity and concentration was determined spectrophotometrically (NanoDrop, ThermoScientific, USA). Until the analysis, DNA samples were stored at $-20^{\circ} \mathrm{C}$.

\section{PCR identification of Fusarium species}

Species-specific PCR primers were used for identification of $F$. graminearum, F. culmorum, F. poae, and $F$. sporotrichioides. The sequences of the primers, the sizes of the amplicons and reference sources are shown in Table 2. Each PCR analysis included DNA of $F$. graminearum, F. culmorum, F. poae, and $F$. sporotrichioides, which served as positive controls and were obtained from internal Fusarium spp. strains collection of the Department of Biotechnology, Human Nutrition and Science of Food Commodities.

Samples were run in $25 \mu$ reactions using $2 \times$ PCR Master Mix (Thermo Scientific Fermentas, Lithuania) with 20 pmol of each primer and $20 \mathrm{ng}$ of DNA on a SensoQuest Labcycler (SensoQuest GmbH, Germany). Thermal cycling conditions specific for each primer pairs were as follows: an initial step at $95^{\circ} \mathrm{C}$ for $5 \mathrm{~min}$ and 5 cycles at $95^{\circ} \mathrm{C}$ for $30 \mathrm{~s}, 66^{\circ} \mathrm{C}$ for $30 \mathrm{~s}$, and $72{ }^{\circ} \mathrm{C}$ for $30 \mathrm{~s}, 5$ cycles at $95^{\circ} \mathrm{C}$ for $30 \mathrm{~s}, 64^{\circ} \mathrm{C}$ for $30 \mathrm{~s}$, and $72{ }^{\circ} \mathrm{C}$ for $30 \mathrm{~s}, 25$ cycles at $95^{\circ} \mathrm{C}$ for $30 \mathrm{~s}, 62^{\circ} \mathrm{C}$ for $30 \mathrm{~s}$, and $72{ }^{\circ} \mathrm{C}$ for $30 \mathrm{~s}$ followed by $72{ }^{\circ} \mathrm{C}$ for $8 \mathrm{~min}$ for $F$. graminearum and F. culmorum, respectively; an

Table 3 Incidence of Fusarium species detected in different sampling regions

\begin{tabular}{lllll}
\hline & Fusarium species $[\%]$ & & & \\
\cline { 2 - 5 } Sampling region & F. graminearum & F. culmorum & F. sporotrichioides & F. poae \\
\hline Eastern Poland $(n=14)$ & $64.29(9$ out of 14$)$ & $21.43(3$ out of 14$)$ & $14.29(2$ out of 14) & $35.71(5$ out of 14) \\
Central Poland $(n=13)$ & $46.15(6$ out of 13$)$ & $7.7(1$ out of 13$)$ & $7.7(1$ out of 13$)$ & $23.08(3$ out of 13$)$ \\
South-western Poland $(n=22)$ & $72.73(16$ out of 22$)$ & $22.73(5$ out of 22$)$ & $0(0$ out of 22$)$ & $9.09(2$ out of 22$)$ \\
North-western Poland $(n=21)$ & $66,67(14$ out of 21$)$ & $9.52(2$ out of 21$)$ & $4.76(1$ out of 21$)$ & $4.76(1$ out of 21$)$ \\
Total $(n=70)$ & $64.29(45$ out of 70$)$ & $15.71(11$ out of 70$)$ & $5.71(4$ out of 70$)$ & $15.71(11$ out of 70$)$ \\
\hline
\end{tabular}


Table 4 Number of Fusarium species detected in different sampling regions

\begin{tabular}{|c|c|c|c|c|c|c|}
\hline \multirow[b]{2}{*}{ Sampling region } & \multicolumn{6}{|c|}{ No. of Fusarium species detected } \\
\hline & 0 & 1 & 2 & 3 & $>1$ & $>2$ \\
\hline Eastern Poland $(n=14)$ & $3(21.42 \%)$ & $4(28.57 \%)$ & $6(42.86 \%)$ & $1(7.14 \%)$ & $11(78.57 \%)$ & $7(50 \%)$ \\
\hline Central Poland $(n=13)$ & $5(38.46 \%)$ & $5(38.46 \%)$ & $3(23.08 \%)$ & $0(0.0 \%)$ & $8(61.54 \%)$ & $3(23.08 \%)$ \\
\hline South-western Poland $(n=22)$ & $6(27.27 \%)$ & $9(40.9 \%)$ & $7(31.82 \%)$ & $0(0.0 \%)$ & $16(72.72 \%)$ & $7(31.82 \%)$ \\
\hline North-western Poland $(n=21)$ & $6(28.57 \%)$ & $13(61.9 \%)$ & $1(4.76 \%)$ & $1(4.76 \%)$ & $15(71.43 \%)$ & $2(9.52 \%)$ \\
\hline Total $(n=70)$ & $20(28.57 \%)$ & $31(44.29 \%)$ & $17(24.29 \%)$ & $2(2.86 \%)$ & $50(71.42 \%)$ & $19(27.14 \%)$ \\
\hline
\end{tabular}

initial step at $95^{\circ} \mathrm{C}$ for $5 \mathrm{~min}$ and 40 cycles at $95^{\circ} \mathrm{C}$ for $30 \mathrm{~s}, 68^{\circ} \mathrm{C}$ for $30 \mathrm{~s}$, and $72{ }^{\circ} \mathrm{C}$ for $40 \mathrm{~s}$ followed by $72{ }^{\circ} \mathrm{C}$ for $8 \mathrm{~min}$ for $F$. sporotrichioides; an initial step at $95^{\circ} \mathrm{C}$ for $3 \mathrm{~min}$ and 38 cycles at $95^{\circ} \mathrm{C}$ for $30 \mathrm{~s}, 62^{\circ} \mathrm{C}$ for $30 \mathrm{~s}$, and $72{ }^{\circ} \mathrm{C}$ for $30 \mathrm{~s}$ followed by $72^{\circ} \mathrm{C}$ for $8 \mathrm{~min}$ for F. poae.

Amplification products were separated by electrophoresis in $1.5 \%$ (wt/vol) agarose gels stained with ethidium bromide in $1 \times$ TBE $1.5 \mathrm{~h}$ at $120 \mathrm{~V}$. DNA bands were then visualized using GelDoc 2000 gel documentation system (BioRad, USA), and sizes of the PCR products were determined by comparison against the migration of GeneRuler 100 bp plus DNA Ladder (Thermo Scientific Fermentas, Lithuania).

Data analysis

Data analyses were carried out: (i) to determine the presence of interactions between species identified, and (ii) to determine whether the occurrence of Fusarium species depends on one of the known factors: geographic location, date of sowing, previous crop, herbicide application in autumn and autumn $\mathrm{N}$ fertilization. Relationships were statistically analyzed by Pearson correlation coefficient using Statgraphics Centurion $\mathrm{XV}$ (Stat Point, Inc.). Significance was assumed at $P \leq$
0.05. Charts were plotted using Microsoft Excel (Microsoft Corp., Redmond, WA, USA).

\section{Results}

Table 3 shows the incidence of Fusarium species identified by the PCR technique in the eastern, central, south-western and north-western regions of Poland. All four species were detected. Species-specific PCR for $F$. graminearum amplified the expected DNA fragment in $64.29 \%$ of stem bases samples of winter wheat. The second most frequently detected species were F. culmorum (15.71\%) and F. poae (15.71\%), followed by F. sporotrichioides $(5.71 \%)$. F. graminearum was recorded four times more often in comparison to $F$. culmorum and $F$. poae. The highest number of $F$. graminearum samples was identified in the southwestern Poland $(72.73 \%)$ in comparison to other regions. The proportion of samples, from all regions, positive for the Fusarium species were: $45: 11: 11: 4$ for $F$. graminearum, F. culmorum, F. poae and F. sporotrichioides, respectively.

Table 4 shows the number of samples with none, one or multiple detections of tested Fusarium species. There were more fields in the eastern Poland with more than

Table 5 Pearson correlation coefficients of Fusarium spp. incidence in stem bases of winter wheat

\begin{tabular}{|c|c|c|c|c|}
\hline Fusarium species & F.graminearum & F.culmorum & Fsporotrichioides & F.poae \\
\hline F. graminearum & - & $0.324 *$ & $\mathrm{~ns}$ & $\mathrm{~ns}$ \\
\hline F. culmorum & $0.324 *$ & - & ns & ns \\
\hline F. sporotrichioides & ns & ns & - & $0.26^{*}$ \\
\hline F. poae & ns & ns & $0.26^{*}$ & - \\
\hline
\end{tabular}

ns not statistically significant

* correlation is significant at $P<0.05$ 
one or two detections of Fusarium species on the stem bases of wheat (11 and 7 out of 14, respectively) than in other regions of Poland included in the study. The number of negative samples for Fusarium species tested was highest in central Poland. Moreover, the number of detected Fusarium species was lowest in the central and northwestern Poland in comparison to the eastern and south-western regions. In all samples considered collectively, only $28.57 \%$ of crops were free of the tested species of Fusarium.

The presence of one species of Fusarium tended to favour the presence of other (Table 5). Overall, the presence of $F$. graminearum appeared to be related to the presence of $F$. culmorum and the presence of $F$. poae seemed to be associated with $F$. sporotrichioides. The correlations found were positive. Correlation coefficient between $F$. culmorum and $F$. graminearum showed slightly stronger interaction in comparison to $F$. sporotrichioides and F. poae. However, both correlations indicated rather weak but noticeable associations between these Fusarium species.

A limited range of preceding crops (forecrops) was present in the surveyed samples, mainly winter rape, maize and winter wheat. Among the 70 wheat fields examined, $35.7 \%$ followed winter rape, $18.6 \%$ maize and $25.7 \%$ winter wheat. Previous crop was the factor associated with the occurrence of Fusarium spp. in wheat stem bases (Table 6). The frequency of $F$. graminearum and $F$. culmorum detections were highest where wheat followed maize. The number of samples with at least one or two Fusarium species identified was also highest in wheat grown after maize in comparison to rape and wheat forecrops. Only about $15 \%$ of samples that followed maize as the previous crop were free of Fusarium species in comparison to $32 \%$ for winter rape and $39 \%$ for winter wheat as forecrops.

The incidence percentage of Fusarium species depended also on the date of sowing (Fig. 2). The frequency of $F$. graminearum and $F$. culmorum detections was highest in samples collected from late sown fields. However, the number of samples positive for $F$. poae and $F$. sporotrichioides was higher in crops sown earlier, in September, rather than in October.

The incidence of $F$. graminearum, F. culmorum and $F$. sporotrichioides in stem bases of winter wheat was lower when herbicide was applied in autumn 2012 (Table 7). The number of Fusarium-free samples was over $100 \%$ higher if herbicide was applied in comparison to unprotected crops. 


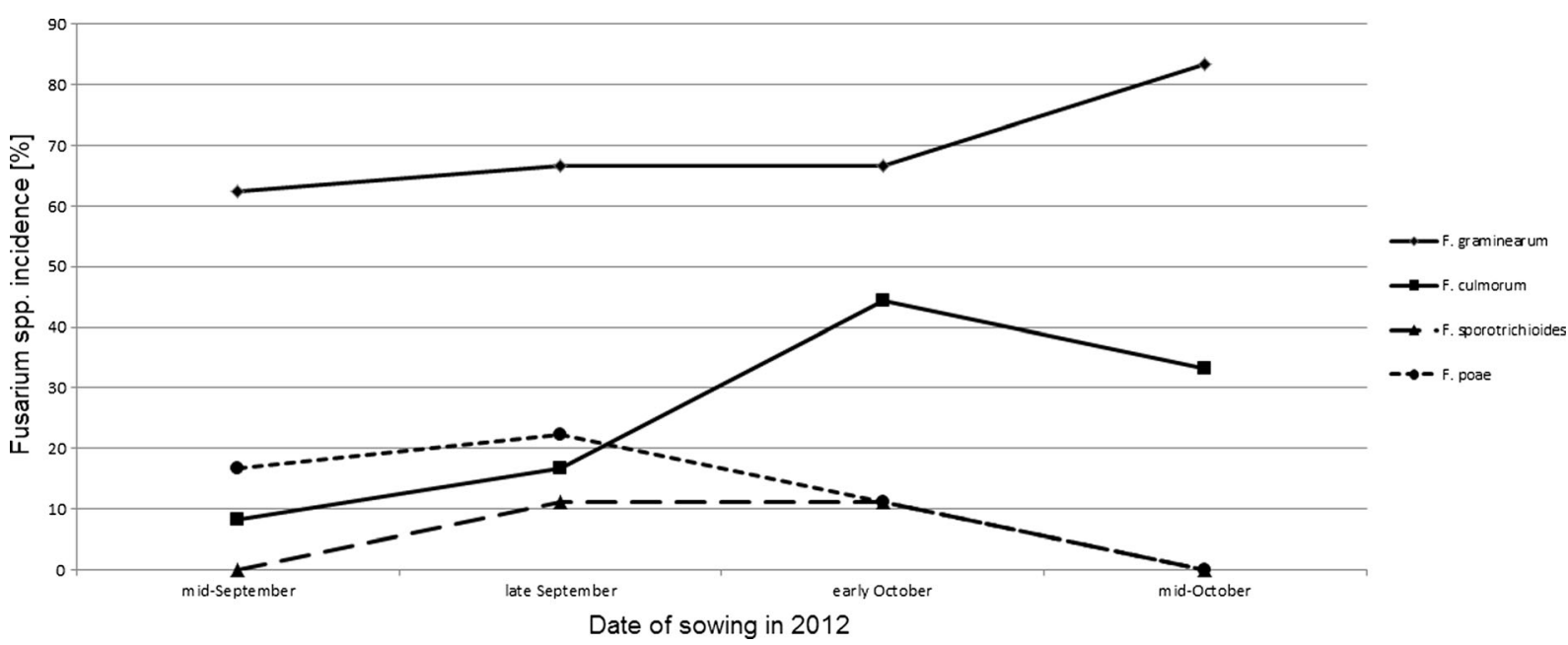

Fig. 2 The percentage of Fusarium spp. incidence in stem bases of winter wheat sown in different months. Early - 1st decade of the month, mid - 2nd decade, late - 3rd decade. Earlier and later dates of sowing were disregarded due to the low number of samples

The level of autumn nitrogen fertilization was also compared with the number of detected Fusarium species (Fig. 3). There was a slight trend detected, but not statistically significant, indicating the positive role of the level of $\mathrm{N}$ fertilization on the number of Fusarium species. About $36 \%$ of samples originated from fields with no fertilization in autumn. Nitrogen fertilization rate below $50 \mathrm{~kg} / \mathrm{ha}$ was recorded in about $39 \%$ of the fields. More than $7 \%$ of the samples originated from the fields with $\mathrm{N}$ fertilization rate above $50 \mathrm{~kg} / \mathrm{ha}$ (data not shown).

\section{Discussion}

Wheat (Triticum aestivum L.) is one of the most extensively cultivated cereals around the world. Fusarium diseases of wheat are very important factors contributing to economic losses and deterioration in grain quality (McMullen et al. 2012). The PCR-based assays can be used for the routine detection and identification of pathogenic fungi from genus Fusarium without morphological determination (Murillo et al. 1998; Moeller et al.
1999; Mulé et al. 2004). The development and use of PCR assays could be also very helpful for early diagnosis and control of Fusarium population on wheat ear and stem base (Ben-Amar et al. 2012).

In this study, F. graminearum was the most frequently detected species occurring on wheat stem bases. The results obtained by other authors in years 1997 to 1999 and from 2000 to 2002 showed that F. culmorum and $F$. poae were the dominant Fusarium species isolated from wheat stem bases in Poland during those years (Narkiewicz-Jodko et al. 2005; Kurowski et al. 2008). The dominance of $F$. culmorum in stem bases of cereals in Poland was also observed from 2001 to 2006 and only few isolates of $F$. graminearum were obtained in 2001 from rye seedlings (Kiecana et al. 2008, 2009). The results obtained in this study suggest that the population structure of Fusarium spp. on wheat stem bases has changed in Poland, and that the predominant species in 2012 was $F$. graminearum. However, until now, F. graminearum species has been detected only occasionally and its high incidence in this study has never been previously observed in Poland on stem bases of cereals.

Table 7 Fusarium spp. incidence in wheat crops in relation to the application of autumn herbicide prior to sowing

\begin{tabular}{|c|c|c|c|c|c|c|c|c|}
\hline $\begin{array}{l}\text { Herbicide } \\
\text { autumn } \\
\text { application }\end{array}$ & $\begin{array}{l}\text { Fusarium } \\
\text { graminearum } \\
\text { incidence [\%] }\end{array}$ & $\begin{array}{l}\text { Fusarium } \\
\text { culmorum } \\
\text { incidence [\%] }\end{array}$ & $\begin{array}{l}\text { Fusarium } \\
\text { sporotrichioides } \\
\text { incidence }[\%]\end{array}$ & $\begin{array}{l}\text { Fusarium } \\
\text { poae } \\
\text { incidence }[\%]\end{array}$ & $\begin{array}{l}\text { No Fusarium } \\
\text { spp. detected } \\
{[\%]}\end{array}$ & $\begin{array}{l}\text { Crops with } 1 \\
\text { species } \\
\text { incidence }[\%]\end{array}$ & $\begin{array}{l}\text { Crops with } 2 \\
\text { species } \\
\text { incidence }[\%]\end{array}$ & $\begin{array}{l}\text { Crops with } 3 \\
\text { species } \\
\text { incidence [\%] }\end{array}$ \\
\hline yes $n=39$ & 59 & 15.4 & 2.6 & 20.5 & 33.3 & 38.5 & 25.6 & 2.6 \\
\hline no $n=25$ & 76 & 20 & 12 & 8 & 16 & 56 & 20 & 4 \\
\hline
\end{tabular}




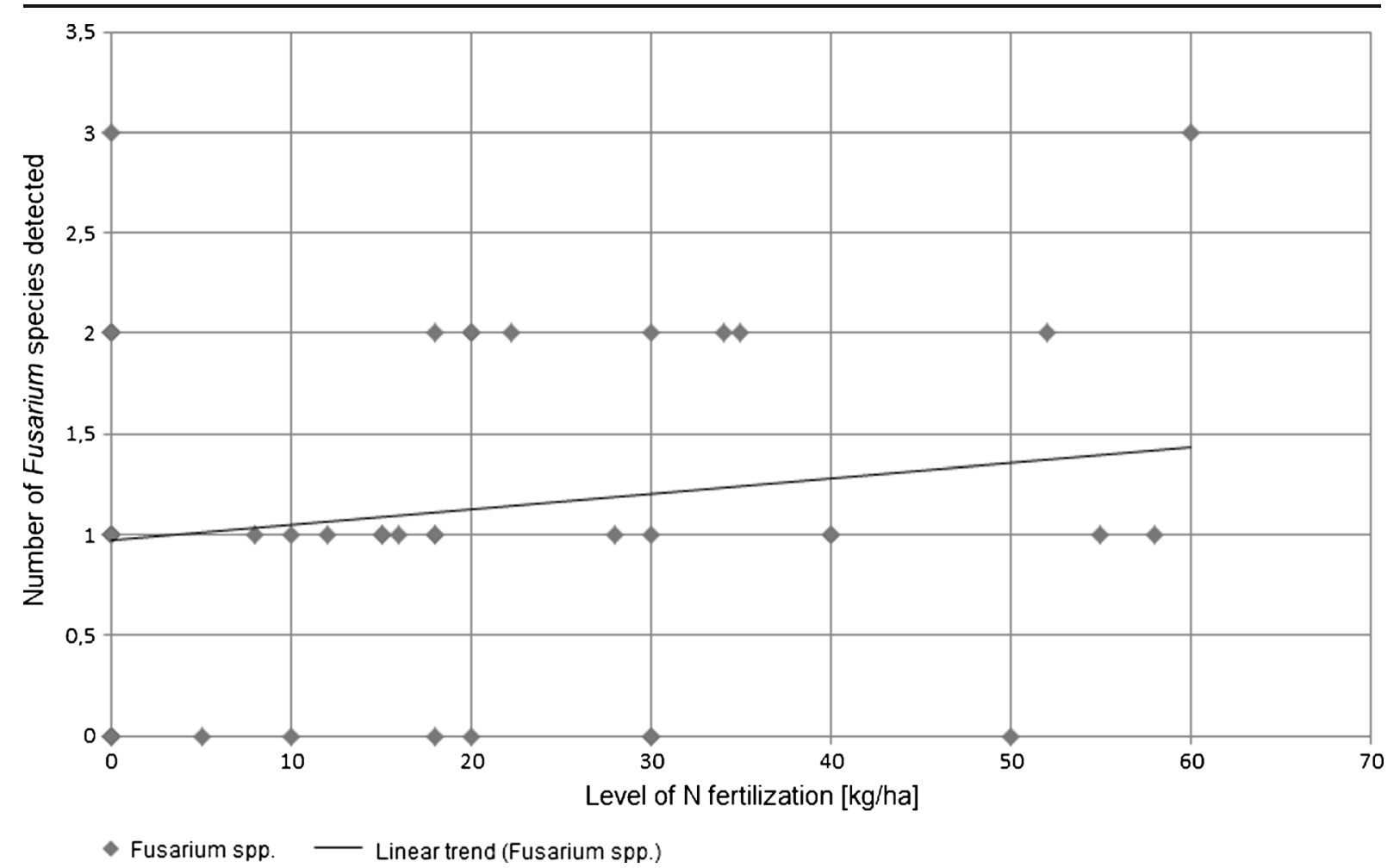

Fig. 3 Number of Fusarium spp. detected according to the level of autumn $\mathrm{N}$ fertilization with line indicating linear trend $(n=61)$

These results may explain the higher number of detections of $F$. graminearum observed lately on wheat kernels in Poland, Netherlands and Austria (Stępień et al. 2008; Weber and Kita 2010; Mielniczuk et al. 2012). $F$. graminearum is one of the most aggressive species in comparison to other fungi of the genus Fusarium and for this reason, a common prevalence of this species on stem bases of winter wheat in Poland should be taken seriously. The progressive dominance of $F$. graminearum over F. culmorum observed in Europe could be explained by climatic conditions during certain growing seasons, the observed changes in climate, or widespread use of feed maize in crop rotation (Scherm et al. 2013). Similarly, the presence of $F$. sporotrichioides in Fusarium population infecting seedlings, roots and stem bases has increased in Poland during recent years (Kiecana et al. 2008; Kiecana and Mielniczuk 2010).

In the current study, there have been also geographic differences in the Fusarium species occurrence, related to the region. The samples from the southwestern Poland had highest frequency of detections of all Fusarium spp. However, the number of samples with at least one or two detections of Fusarium species on the stem base of wheat was also highest in the eastern Poland. There are several reports describing the structure of Fusarium population in Poland, based on the regions of the country. Goliński et al. (2010) compared two locations, Cerekwica near Poznan (centralwestern Poland) and Sitaniec near Zamość (south-eastern Poland). This author observed highest rate of Fusarium infections and level of mycotoxin biosynthesis in the south-eastern Poland. However, no detailed studies have been published on the distribution of Fusarium spp. in Poland on wheat stem bases to compare with the results obtained in this study. Most of the studies focus on one location (Narkiewicz-Jodko et al. 2005; Kurowski et al. 2008; Kiecana et al. 2008, 2009).

The analysis of co-occurrence of all cases studied showed correlation of $F$. graminearum with $F$. culmorum and $F$. poae with $F$. sporotrichioides. Interaction between $F$. graminearum and $F$. culmorum can be explained by their coexistence as a complex of main species on the same plant (Nicholson et al. 1998). Interactions between species from the genus Fusarium has been observed previously, although most of them had a character of growth inhibition, e.g., F. moniliforme can suppress the growth of $F$. graminearum. Negative correlation has also been found between $F$. moniliforme and 
both F. graminearum and F. subglutinans (Reid et al. 1999). In addition, F. culmorum was showed to suppress the growth of M. nivale (Simpson et al. 2004) and $F$. graminearum reduced the growth rate of F. moniliforme and F. proliferatum (Marin et al. 1998). These relationships are likely to be explained by the influence of other associated factors, i.e., forecrop and date of sowing that emerged from further analyses of samples. However, a very interesting co-incidence was also noted in these correlations of Fusarium species from the same Fusarium sections: Discolor (F. graminearum and F. culmorum) and Sporotrichiella (F. poae and F. sporotrichioides) (Watanabe et al. 2011).

Our data supports the findings that previous crop has an influence on Fusarium incidence (Wiese 1987). Among analyzed forecrops, maize promoted the occurrence of Fusarium spp. and this influence was highly significant in the case of $F$. graminearum and F. culmorum. This factor could positively affect cooccurrence of these species. Furthermore, $F$. graminearum is described as a major pathogen of maize stalks and ears (Waalwijk et al. 2003; Osborne and Stein 2007). The presence of maize in the structure of crop rotations in this study could explain the domination of $F$. graminearum over F. culmorum (Scherm et al. 2013).

Results of the current study indicate that the date of sowing of winter wheat could also influence the incidence of Fusarium in spring. Later date of sowing increased the incidence of $F$. graminearum and F. culmorum, while the number of samples positive for $F$. sporotrichioides and F. poae was highest in earlier sown crops. This could be the second factor responsible for the correlation between these Fusarium species. These findings confirmed results obtained by Subedi et al. (2007) who showed that the later the sowing date, the greater the incidence of Fusarium spp. Furthermore, the incidence of Fusarium-damaged kernels was also higher after later sowing (Ma et al. 2013). Since $F$. graminearum and $F$. culmorum represent a significant part of Fusarium spp. population present on wheat stem bases among species analyzed in this study, it should be recommended to avoid late dates of sowing.

The presence of weeds on the field might promote the occurrence of pathogenic fungi. Weeds are one of the potential sources of Fusarium inoculum (Altinok 2013). Our findings confirmed the negative impact of herbicide application in autumn on Fusarium spp. incidence in spring. However, the effect of herbicides on plant pathogens is not clear. The application of herbicides can result in a decrease of the severity of diseases but they can also trigger opposite effects (Velini et al. 2010; Lemańczyk 2012).

The level of autumn nitrogen fertilization had no effect on Fusarium spp. incidence. Several recent studies have shown that FHB infection and Fusarium mycotoxin contaminations were increased with higher rate of $\mathrm{N}$ application (Lemmens et al. 2004; Burgt et al. 2011), whereas other studies did not reveal any significant effects of $\mathrm{N}$ application on FHB (Váňová et al. 2008; Yoshida et al. 2008).

\section{Conclusions}

PCR-assay can be used for early detection of Fusarium spp. even if symptoms of fungi presence are not visible on plant. Among Fusarium species tested, F. graminearum was most frequently isolated from stem bases of wheat. The occurrence of $F$. graminearum and $F$. culmorum as well as $F$. poae and $F$. sporotrichioides was weakly correlated. Maize most highly promoted the incidence of Fusarium spp among forecrops analyzed. Later date of sowing increased the incidence of $F$. graminearum and F. culmorum in the spring and decreased the incidence of $F$. poae and F. sporotrichioides. Application of herbicides in autumn reduced the population of Fusarium. The rate of autumn $\mathrm{N}$ fertilization did not affect the number of Fusarium detections.

Open Access This article is distributed under the terms of the Creative Commons Attribution License which permits any use, distribution, and reproduction in any medium, provided the original author(s) and the source are credited.

\section{References}

Altinok, H. H. (2013). Fusarium species isolated from common weeds in eggplant fields and symptomless hosts of Fusarium oxysporum f. sp. melongenae in Turkey. Journal of Phytopathology, 161(5), 335-340.

Baturo, A. (2006). Effect of thermotherapy, grain treatment and leaf spraying with biological control agents on spring barley Hordeum vulgare health in organic system. Phytopathologia, 41, 15-26.

Ben-Amar, A., Oueslati, S., Ghorbel, A., \& Mliki, A. (2012). Prediction and early detection of mycotoxigenic Fusarium culmorum in wheat by direct PCR-based procedure. Food Control, 23, 506-510. 
Bottalico, A., \& Perrone, G. (2002). Toxigenic Fusarium species and mycotoxins associated with head blight in small-grain cereals in Europe. European Journal of Plant Pathology, $108,611-624$.

Braithwaite, M., Alexander, B. J. R., \& Adams, R. L. M. (1998). In: Nationwide survey of pests and diseases of cereal and grass seed crops in New Zealand. 2. Fungi and bacteria. Proceedings of the 51st New Zealand Plant Protection Conference, New Zealand Plant Protection Society, 51-9.

Burgess, L. W., Backhouse, D., Summerell, B. A., \& Swan, L. J. (2001). Crown rot of wheat. In B. A. Summerell, J. F. Leslie, D. Backhouse, W. L. Bryden, \& L. W. Burgess (Eds.), Fusarium. Paul E. Nelson Memorial Symposium (pp. 271294). St. Paul Minnesota: American Phytopathological Society Press.

Champei, A., Doré, T., \& Fourbet, J. F. (2004). Fusarium head blight: epidemiological origin of the effects of cultural practices on head blight attacks and the production of mycotoxins by Fusarium in wheat grains. Plant Science, 166, 1389-1415.

Cromey, M. G., Parkes, R. A., \& Fraser, P. M. (2006). Factors associated with stem base and root diseases of New Zealand wheat and barley crops. Australasian Plant Pathology, 35, 391-400.

Demeke, T., Clear, R. M., Patrick, S. K., \& Gaba, D. (2005). Species-specific PCR-based assays for the detection of Fusarium species and a comparison with the whole seed agar plate method and trichothecene analysis. International Journal of Food Microbiology, 103, 271-284.

Gargouri, S., Mtat, I., Kammoun, L. G., Zid, M., \& Hajlaoui, M. R. (2011). Molecular genetic diversity in populations of Fusarium pseudograminearum from Tunisia. Journal of Phytopathology, 159, 306-313.

Goliński, P., Waśkiewicz, A., Wiśniewska, H., Kiecana, I., Mielniczuk, E., Gromadzka, K., et al. (2010). Reaction of winter wheat (Triticum aestivum L.) cultivars to infection with Fusarium spp.: mycotoxin contamination in grain and chaff. Food Additives and Contaminants Part A-chemistry Analysis Control Exposure \& Risk Assessment, 27(7), 1015-1024.

Jaczewska-Kalicka, A. (2001). Występowanie chorób i straty plonu pszenicy ozimej, ze szczególnym uwzględnieniem wpływu warunków klimatycznych. Progress in Plant Protection/Postepy w Ochronie Roślin, 41(2), 607-616.

Jurado, M., Vázquez, C., Marin, S., Sanchis, V., \& González-Jaén, M. T. (2006). PCR-based strategy to detect contamination with mycotoxigenic Fusarium species in maize. Systematic and Applied Microbiology, 29, 681-689.

Jurado, M., Vázquez, C., Patino, B., \& González-Jaén, M. T. (2005). PCR detection assays for the trichotheceneproducing species Fusarium graminearum, Fusarium culmorum, Fusarium poae, Fusarium equiseti and Fusarium sporotrichioides. Systematic and Applied Microbiology, 28, 562-568.

Kiecana, I., Cegiełko, M., \& Mielniczuk, E. (2009). The occurrence of Fusarium spp. on winter rye (Secale cereale L.) and susceptibility of different genotypes to infection with F. avenaceum (Fr.) Sacc. and F. culmorum (W.G.Sm.). Biul IHAR, 252, 151-161.

Kiecana, I., \& Mielniczuk, E. (2010). Fusarium head blight of rye (Secale cereale L.). Acta Agrobotanica, 63(1), 129-135.
Kiecana, I., Mielniczuk, E., \& Cegiełko, M. (2008). Fungi infecting roots and stem bases in oat (Avena sativa L.). Biul IHAR, 247, 73-79.

Klein, T. A., Burgess, L. W., \& Ellison, F. W. (1991). The incidence and spatial patterns of wheat plants infected by Fusarium graminearum group 1 and the effect of crown rot on yield. Australian Journal of Agricultural Research, 42, 399-407.

Korbas, M. (2004). Choroby podstawy źdźbła, możliwości i perspektywy zwalczania. Progress in Plant Protection/ Postęy w Ochronie Roślin, 44(1), 147-154.

Kulik, T., Fordoński, G., Pszczółkowska, A., Płodzień, K., \& Łapiński, M. (2004). Development of PCR assay based on ITS2 rDNA polymorphism for the detection and differentiation of Fusarium sporotrichioides. FEMS Microbiology Letters, 239(1), 181-186.

Kurowski, T. P., Marks, M., Orzech, K., \& Kowalska, E. (2008). Sanitary state and yielding of Winter wheat as dependent on soiltillage system. Zeszyty Problemowe Postepów Nauk Rolniczych, 531, 95-103.

Lemańczyk, G. (2012). Severity of root and stembase diseases ofspring cereals as affected by chemical control of weeds. Progress in Plant Protection/Postepy $w$ Ochronie Roślin, 52(2), 369-376.

Lemmens, M., Haim, K., Lew, H., \& Ruckenbauer, P. (2004). The effect of fertilization on Fusarium head blight development and deoxinivalenol contamination in wheat. Journal of Phytopathology, 152, 1-8.

Liebert, B. (2013). Create, collaborate and share advanced custom maps with Google Maps Engine Lite (Beta). Google Maps. Google, Inc. [http://google-latlong.blogspot.com/2013/03/ create-collaborate-and-share-advanced.html]. Accessed 20 May 2013.

Łukanowski, A. (2009). Winter wheat stem base infestation and fungal communities occurring on stems in dependence on cropping system. Phytopathologia, 53, 43-55.

Ma, B. L., Subedi, K. D., Xue, A. G., \& Voldeng, H. D. (2013). Crop management effects on fusarium head blight, fusarium-damaged kernels and deoxynivalenol concentration of spring wheat. Journal of Plant Nutrition, 36(5), 717-730.

McMullen, M., Bergstrom, G. C., DeWolf, E., Dill-Macky, R., Hershman, D., Shaner, G., \& Van Sanford, D. (2012). A unified effort to fight an enemy of wheat and barley: Fusarium head blight. Plant Disease, 96, 1712-1728.

Marin, S., Sanchis, V., Ramos, A. J., Vinas, I., \& Magan, N. (1998). Environmental factors, in vitro interactions, and niche overlap between Fusarium moniliforme, $F$. proliferatum and $F$. graminearum, Aspergillus and Penicillium species from maize grain. Mycological Research, 102, 831-837.

Mielniczuk, E., Kiecana, I., \& Cegiełko, M. (2012). Fungi infecting the roots and stem base of winter rye (Secale cereale L.) grown in the Lublin region (Poland). Acta Agrobotanica, 65(3), 85-92.

Moeller, E. M., Chelkowski, J., \& Geiger, H. H. (1999). Speciesspecific PCR assays for the fungal pathogens Fusarium moniliforme and Fusarium subglutinans and their application to diagnose maize ear rot. Journal of Phytopathology, 147, 497-508. 
Monds, R. D., Cromey, M. G., Lauren, D. R., di Menna, M., \& Marshall, J. (2005). Fusarium graminearum, F. cortaderiae and $F$. pseudograminearum in New Zealand: molecular phylogenetic analysis, mycotoxin chemotypes and co-existence of species. Mycological Research, 109, 410-420.

Mulé, G., González-Jaén, M. T., Hornok, L., Nicholson, P., \& Waalwijk, C. (2005). Advances in molecular diagnosis of toxigenic Fusarium species. Food Additives and Contaminants, 22, 316-323.

Mulé, G., Susca, A., Stea, G., \& Moretti, A. (2004). A speciesspecific PCR assay based on the calmodulin partial gene for identification of Fusarium verticillioides, F. proliferatum and F. subglutinans. European Journal of Plant Pathology, 110, 495-502.

Murillo, I., Cavallarin, L., \& San Segundo, B. (1998). The development of a rapid assay for the detection of Fusarium moniliforme. European Journal of Plant Pathology, 104, 301-311.

Narkiewicz-Jodko, M., Gil, Z., \& Urban, M. (2005). Stem base rot of winter wheat by Fusarium spp. - causes and effects. Acta Agrobotanica, 58(2), 319-332.

Nicholson, P., Simpson, D. R., Weston, G., Rezanoor, H. N., Lees, A. K., Parry, D. W., et al. (1998). Detection and quantification of Fusarium culmorum and Fusarium graminearum in cereals using PCR assays. Physiological and Molecular Plant Pathology, 53(1), 17-37.

Niessen, L., Schmidt, H., \& Vogel, R. F. (2004). The use of tri5 gene sequences for PCR detection and taxonomy of trichotheceneproducing species in the Fusarium section Sporotrichiella. International Journal of Food Microbiology, 95, 305-319.

Osborne, L. E., \& Stein, J. M. (2007). Epidemiology of Fusarium head blight on small-grain cereals. International Journal of Food Microbiology, 119(1-2), 103-108.

Parry, D. W., Jenkinson, P., \& McLeod, L. (1995). Fusarium ear blight (scab) in small grain cereals - A review. Plant Pathology, 44, 207-238.

Parry, D. W., \& Nicholson, P. (1996). Development of a PCR assay to detect Fusarium poae in wheat. Plant Pathology, 45, 383-391.

Reid, L. M., Nicol, R. W., Ouellet, T., Savard, M., Miller, J. D., Young, J. C., et al. (1999). Interaction of Fusarium graminearum and $F$. moniliforme in Maize Ears: disease progress, fungal biomass, and mycotoxin accumulation. Phytopathology, 89(11), 1028-1037.

Scherm, B., Balmas, V., Spanu, F., Pani, G., Delogu, G., Pasquali, M., et al. (2013). Fusarium culmorum: causal agent of foot and root rot and head blight on wheat. Molecular Plant Pathology, 14(4), 323-341.
Simpson, D. R., Thomsett, M. A., \& Nicholson, P. (2004). Competitive interactions between Microdochium nivale var. majus, M. nivale var. nivale and Fusarium culmorum in planta and in vitro. Environmental Microbiology, 6(1), 79-87.

Smiley, R. W., \& Patterson, L. M. (1996). Pathogenic fungi associated with Fusarium foot rot of winter wheat in semiarid Pacific Northwest USA. Plant Disease, 80, 944-949.

Stępień, Ł., Popiel, D., Koczyk, G., \& Chełkowski, J. (2008). Wheat-infecting Fusarium species in Poland - their chemotypes and frequencies revealed by PCR assay. Journal of Applied Genetics, 49(4), 433-441.

Subedi, K. D., Ma, B. L., \& Xue, A. G. (2007). Planting date and nitrogen effects on Fusarium head blight and leaf spotting diseases in spring wheat. Agronomy Journal, 99(1), 113-121.

van der Burgt, G. J. H. M., Timmermans, B. G. H., Scholberg, J. M. S., \& Osman, A. M. (2011). Fusarium head blight and deoxynivalenol contamination in wheat as affected by nitrogen fertilization. NJAS - Wageningen Journal of Life Sciences, 58(3-4), 123-129.

Váňová, M., Klem, K., Míša, P., Matušinsky, P., Hajšlová, J., \& Lancová, K. (2008). The content of Fusarium mycotoxins, grain yield and quality of winter wheat cultivars under organic and conventional cropping systems. Plant, Soil and Environment, 54, 395-402.

Velini, E. D., Trindade, M. L. B., Barberis, L. R. M., \& Duke, S. O. (2010). Growth regulation and other secondary effects of herbicides. Weed Science, 58(3), 351-354.

Waalwijk, C., Kastelelin, P., de Vries, I., Kerenyi, Z., van der Lee, T., \& Hesselink, T. (2003). Major changes in Fusarium spp. in wheat in the Netherlands. European Journal of Plant Pathology, 109, 743-754.

Watanabe, M., Yonezawa, T., Lee, K., Kumagai, S., SugitaKonishi, Y., Goto, K., et al. (2011). Molecular phylogeny of the higher and lower taxonomy of the Fusarium genus and differences in the evolutionary histories of multiple genes. BMC Evolutionary Biology, 11, 322.

Weber, R., \& Kita, W. (2010). Effects of tillage system and forecrop type on frequency of Fusarium culmorum and $F$. avenaceum occurrence on culm base of some winter wheat (Triticum aestivum L.) cultivars. Acta Agrobotanica, 63(1), 121-128.

Wiese, M. V. (1987). Compendium of wheat diseases (2nd ed.). St. Paul: American Phytopathological Society.

Yoshida, M., Nakajima, T., \& Tonooka, T. (2008). Effect of nitrogen application at anthesis on FHB and mycotoxin accumulation in breadmaking wheat in the western part of Japan. Journal of General Plant Pathology, 74, 355-363. 